\title{
(Auto)biography and Social Theory: A Perspective on the Life and Work of Ben Agger (1953-2015)
}

\author{
Lukas Szrot
}

Ben Agger carved out a space for the author in a society—and in many ways, a sociology—which had, in the latter decades of the twentieth century, fought for self-recognition and professional prestige by attempting to excise the appearance and language of subjectivity. In homage to his effort, what follows is not social theory, biography, or autobiography, but all of these, and perhaps something else not readily genre-specific. For Ben Agger was also a mentor and a friend. Piecing together this tale involves time-travel of a sort-not merely the linear time travel of "looking backward," but something non-linear-I did not read Ben's works in the order that he wrote them, and when writing thoughts do not come (at least to me) in a tidy, temporally-bounded flow, and thus my own reading of his life and work reflects this unavoidable non-linearity. Additionally, Ben Agger was a multifaceted person-a husband and father, a marathon runner, a prolific writer by any standard, a member of the University of Texas at Arlington Department of Sociology and Anthropology faculty, and more. I knew Ben through his writings, the courses he taught, and the times we conversed, which were many. My recollection is an episodic series of moments, not exhaustive in biographical or theoretical accounting. What follows is a personal narrative tinged with hues of the postmodern, a smattering of his life and work from one perspective that embraces - better yet, celebrates - the messiness, ambiguities, and complexity of social interactions in lived human lives.

\section{Ben Agger as Teacher and Mentor}

Dr. Agger taught an undergraduate social theory course at the University of Texas at Arlington in 2003. At the time I was this awkward, scrawny twenty-year-old philosophy major who read Nietzsche and stomped across campus with thrash metal blaring through my headphones. I was considering a double major, and so I enrolled in it. The course was compelling and refreshing, featuring a discussion of the sociology triumvirate of Marx, Weber, and Durkheim contextualized by thinkers ranging from Plato to Descartes and Heidegger to Sartre. Dr. Agger seemed to have an encyclopedic memory, lecturing with few or no notes (he was well-known for his distaste for PowerPoint slide shows, I learned later), his lectures a nonlinear, dialectical dance which often started, touched upon, or ended with Marx or the Frankfurt School. The mid-term exam was essay format, completed in the nearby computer lab. He printed out copies of my completed essay, with my name blacked out, and distributed them to the class. "This is what social theory looks like." I was a rather arrogant young man with many harsh lessons ahead of him, but found this strangely humbling. After this, I thanked him on the way out of class, and we talked a bit — the first of many such brief conversations, in which I felt comfortable voicing my growing disenchantment with the Anglophone analytic philosophy that had come to dominate the tradition. Though it would be many years, again due to Ben's guidance, that I would come to find a voice that had capture this disenchantment in the second half of Herbert Marcuse's (1964) One-Dimensional Man. 
I do not remember many of the details of our conversations now, but, I know we also touched on ancient philosophy, particularly the propensity of the ancient Greeks to place special emphasis on the normative concerns. Ethics in modern philosophy, if I may be excused for recounting a youthfully naïve overgeneralization, often seemed to focus on sterile conceptual hair-splitting, apparently remote from providing guidance, inspiration, or deliberation toward "the good life." The role of normative_ and political—concerns as discussed by Ben in his social theory class emerged at the fore, as did their intimate connection to questions of epistemology and ontology. Some of those ideas that emerged back in 2003 during those brief chats remain foundational to my current academic interests and pursuits.

Back then I was going to be a college professor-or a professional musician-I could not decide which. After completing a bachelor's degree in 2004, and perhaps to the dismay of many, I opted for the latter route. During the interim, I lost touch with Ben, as well as the philosophy department. I learned later that my philosophy advisor passed away in 2008. It was devastating, as was the gradual realization that music, at least as I had stubbornly pursued it, afforded a generally lousy lifestyle and few opportunities for-well—stability of any sort. It was not until 2013 that I returned to academe, this time in pursuit of a graduate degree in sociology. Hesitantly, I reached out to Dr. Agger, who still, after all that time, remembered me, and was happy to write a letter of recommendation that I might enter the graduate program in his department that fall.

That summer I re-read Postponing the Postmodern, in my opinion one of Ben's best, and most underrated, books. During the final editorial stages, the September 11, 2001 World Trade Center attacks had happened, which had captured the attention of many social theorists, including Ben, who devoted an epilogue to the events. The aftermath saw bursts of lucidity and insight of the sort that seem to drive good social theory, an inherent tension and nuance that falls short of exhaustion or ambivalence, that such events provoked. Social theory at times seems to operate best when perched dramatically between hope and fear, between utopia and dystopia, and the aftermath of the 9.11 attacks marked this notably. Agger (2002) argued in the afterword, with Habermas, that modernity remains incomplete because many of the world's people do not yet enjoy wealth, or even have enough to survive, and political democracy is hardly found everywhere. Yet there are two more telling, classic "Agger-esque" passages, first: "And even where it [democracy] is found, there is real concern that democracy is simply a smoke screen for the interests of capital, an 'executive committee of the bourgeoisie,' as Marx termed the state" (201). This epitomizes Ben in many ways: courageous, undogmatic, and matter-of-fact. His writing at its best reflects his speech, and teaching, at once polished and down-to-earth, inviting additional thought and deliberation. I wonder today whether it is accurate or analytically useful to label the state as such, or whether extant liberal democracies are really window-dressings for something more insidious. Yet this quote, at once forceful and controversial, neither dogmatically avers nor licenses obsequiousness.

The ideas expressed in a second quotation, however, run deeper, and seem to have haunted much of Agger's scholarly career: "And even where secular science prevails, scientism (a belief that science will solve all social problems) and positivism function ideologically, as belief systems that cloak the status quo in permanence and ontological necessity" (ibid.). In his graduate social theory course that fall, I often heard him use the phrase "stand outside the world," a description of the apparent effort to write, and do, sociology, as if one occupied a "view from nowhere," a sort of Archimedian point of reference without a point of reference. It was not science, but the monster of scientism, usually termed positivism, with whom Ben did battle. In Postponing the Postmodern, he declares that "A sociology without any numeracy whatsoever, from census data to fertility rates, from average income data to crime statistics, would be as impoverished as a sociology that denies that authorial voice, and with it theory and qualitative method" (ibid. 9). I did not realize that there was something that could be read rather triumphantly in his proclamation here until years later. He was also fond of a phrase_- "science is fiction" —which made me squirm in my seat. Growing up on a steady diet of popular science books and Carl Sagan, noting how fragile was the "candle in the dark" that illuminated the wonders of the distant past, and could unlock the vast and ancient universe, the atomic and subatomic world, and life itself, I was taken aback. I spent a great deal of time during my first year as a graduate student studying the creation-evolution controversy in American education-if science was fiction, did that mean Intelligent Design, Young Earth Creationism...Flat Earth theory...had a place in public school science classrooms after all? The difference between science and fiction seemed clear to me-and it matters what's true.

\section{How could science be fiction? I wondered.}

I was working full-time at my father's machine shop that fall, newly-married and with no car and little money or credit, taking six credit hours without funding by living in relative austerity and with help from family and friends (as so many of us do). When I did get a car later that semester, a 1980-something Mercedes that my dad and some of 
the guys down at the shop overhauled (which I affectionately called the "Frankenbenz"), arriving on campus in the late afternoon frequently meant parking far from class, and Ben often drove me, as well as any other students who wanted a ride, to our cars in an old red van which issued an intermittent clunking sound near the passenger-side front axle. Years of working with machines led me to inquire. Ben noted it, and asked me what it was-I diagnosed a bad ball joint. That van must have had over 300,000 miles on it, not what one would expect of a full professor and author of over a dozen books. On one such drive, we discussed Max Weber, particularly the idea that scientific knowledge had led to an increased disenchantment of the world, the topic that would become my first graduate theory term paper, and the springboard for a Master's thesis. On another journey to the distant parking lot, he asked me how the first semester as a grad student was going. I replied, with some hesitation: "I am really enjoying the material, and my courses, but I am left wondering... what exactly sociology is."

Ben replied with a grin: "When you figure it out, let me know." I was fascinated by religion as well as social theory, and had also developed a love for statistics. He unabashedly encouraged the intellectual growth of his students, wherever it should take them. In an existentialist, almost Sartrean sense, he spoke of the centrality of one's effort to "find your truth" — the worst sin was not leaving academe for the private sector or failing to attain-or even pursue - a tenure-track academic job, but failing yourself by living in bad faith. Ben Agger discussed Russell Jacoby's The Last Intellectuals near the end of that semester, which piqued my interest though it would be years before I sat down to read it. An opportunity to bring together the critical theory of the course and my interest in religion presented itself in the form of a class presentation. I was eager to impress him, and to prove I was capable of graduate study, and offered to discuss Marcuse and Weber-rationalization and disenchantment alongside onedimensional thought.

I wrestled with the connection between morality and rationality, questioning some of the more radical tenets of Marxism and wondering aloud how the blame for the Holocaust indeed belonged at the feet of the Enlightenment (it would be some time before I read the rather gloomy Dialectic of Enlightenment). It came into sharp relief by the end of Ben's course that the move toward postmodernity, for some, brings new challenges, perhaps including a form of historical amnesia: "Modernism, or so it is imagined, was old enough to remember a time when there were firm foundations to human existence, and was still reeling from the shock of their being kicked rudely away" (Eagleton 2003:57), while "Postmodernism is too young to remember a time when there was (so it was rumored) truth, identity and reality, and so feels no dizzying abyss beneath its feet" (ibid. 58). At times I feel like a modern person living in a postmodern world.

For Ben, "Selfhood today is experienced primarily as anxiety, even desperation. The anxiety concerns what Max Weber has called the loss of meaning, which seems to many to be an inevitable byproduct of modernity, including capitalism. The loss of meaning is occasioned by a peculiarly ahistorical view of the world, which is flattened into an eternal present. The world we experience appears to exhaust all possible worlds. We don't know who we are, or what formed us" (Agger 2002:3). As one who grew up Catholic, studied philosophy, pursued music, and was rewarded with a sensation akin to skydiving without a ground toward which to travel—or a parachute-these ideas spoke volumes. Maybe there is a way to medicalize this sensation_by calling it "anxiety" perhaps—as a gesture toward bringing it under expert control. I could be "normalized," statistically and psychically, as Stivers (1999) might put it in his provocative Technology as Magic, "treated" for a disease-I could belong to a statistically-created social category (102); I could trade existential unease as a quality of the modern condition for a reduction of my standard error in relation to a regression line.

During the time I knew Ben, I thought myself "religiously unmusical," to borrow Weber's (Gerth and Mills 1946:25) famous euphemism, identifying as an atheist, though I increasingly came to wonder what it even means to be "religious." After Nietzsche, the very definition of what it means to be religious slides toward undecidability. Max Horkheimer once called religion "The not-yet-strangled impulse that insists that reality should be otherwise, that the spell will be broken and turn toward the right direction" (Quoted in Neiman 2003:306). If this is religion, is critical theory, in some important sense, a religious project? I no longer use the word "atheist." I hear music now, to extend Weber's metaphor. It is beautiful, indeed. But is it "the" music? It does not seem to emanate exclusively from any one of the world's religious traditions, and I find the term "spiritual" irksome and hopelessly amorphous.

A verbose and angst-laden e-mail containing some of the above arrived on Dr. Agger's desk at some point in early 2014, and he began his reply with the phrase, "please, call me Ben." He encouraged his students to do so, having a dislike for hierarchy and formality, but many admittedly were intimidated by his erudition (myself included for some time after this), and still referred to him title-first. By some stroke of happenstance, I was able to reapply for funding that December, and received a full fellowship beginning that January. I said a bittersweet good-bye to 
my father's machine shop, and to many of the great men and women with whom I had worked, both there and as a struggling local musician. That second semester, Ben taught a course called "Fast Food and Fast Bodies in Fast Capitalism," delving into the body as a site most affected by the speed-ups of capitalism, the high costs of fast food, and the inspiring efforts put in by marathon runners. It was revealing-Ben was a regular runner, and had completed several marathons, being at the time in his early sixties. He was an avowed ethical vegan, exposing students to the cruelties of the factory farming system that produced the vast majority of our meat products (something I was exposed to at a relatively early age during a part-time job at a chicken slaughterhouse), and an admitted coffee addict (not an especially unusual vice in academia so far as I can tell, and one to which I am no exception). I tried running a few $5 \mathrm{~K}$ s that year, but I am a little overweight (so says the Body Mass Index chart anyway), and have a bad lower back; it became clear after a few attempts that walking and hiking are more my speed.

There was a lot of writing, journaling, and feedback during that course (Ben was resistant to exams and grading as vestiges of the positivism he deplored), which enjoyed a broad interdisciplinary popularity. For the term paper assignment, I wrote a critical theory piece on alcohol with Ben's approval (he called alcohol "the elephant in the room," something we did not much discuss as a class), exploring the cultural and ideological bases of the diseasing of behaviors as Peele (1989) critically called them in Diseasing of America. In Diseases of the Will, Marianne Valverde (1998) paraphrased American physician Benjamin Rush, whose silhouette graces the logo of the American Psychiatric Association, and who was one of the signers of the U.S. Constitution. In the 1780s he argued that habitual drunkenness should be regarded not as a bad habit but as a disease, a "palsy of the will" (quoted on 2). Questions of will, and agency, are raised anew when behavior becomes medicalized.

At the end of that semester, I had to choose a thesis advisor, and I asked Ben if he would be willing to work with me. I had talked to a few other professors about the logistics of academia, and their expectations, becoming ever more aware of the stakes. Ben was willing to work with me, and after our talk I was convinced that theory would best suit my academic goals and temperament. He noted the emphasis on method and technical know-how in many of the sociology departments in the United States, as well as the expectation that one would work on "research teams" or co-publish with faculty or peers. "You strike me as a lonely scholar," he noted. In Public Sociology, Ben announces: "An epistemological pluralist, I am intolerant only of intolerance! That is, the positivist program as I understand it necessarily excludes non-positivist ways of knowing and writing" (Agger 2000:231). When I asked him about my Master's Thesis, he was emphatically uninterested in chairing a "scientific method" sociology project (a data-driven quantitative project which tested hypotheses and was written in conformity with journal article norms), though he was interested in, and knowledgeable about, science generally. I too am what he would call an epistemological pluralist - science, for me, simply suggests a systematic way of understanding the world. It was not the brainchild of seventeenth-century white men, but the outcome of the central survival skills of the human species since prehistory. And sociology is stronger, I contend, not weaker, for its breadth of epistemic and methodological work.

\section{| (Re)reading (Social) Science: Ben Agger's Critique of Sociology and the Academy}

Around that time Ben put me in touch with the independent American philosophy and critical theory journal Telos, where I eventually became an intern and to whom I still proudly contribute writings and conference presentations today. These factors led to many early morning meetings over coffee at Starbucks and a conference course in the sociology of knowledge the following semester, during which Ben introduced me to the pioneering efforts of Karl Mannheim in Ideology and Utopia, (1936). That moment was preceded by a series of forays into the philosophy of social science, particularly the fierce critiques of Marx via Karl Popper in The Open Society and Its Enemies (1962) and the work of philosopher Robert D'Amico (1991) on "Popper, Adorno, and the Methodology Dispute." The first piece of my work ever to be published was a short Telos thread on the relationship between critical theory, utopia, and revolution via Adorno, on the one hand, and piecemeal reform and fallibilism via Popper on the other (Szrot 2014). While I still think Popper was more than a little unfair to Hegel, as well as Mannheim, his critiques of Plato and Marx — nuanced, complex, and insightful—still challenge me today.

Ben had clearly read these works, and was comfortable discussing them over coffee. But the "elephant in the room" that fall was my thesis proposal, and the journey toward enrolling in a Ph.D. program at the end of the semester (UT Arlington did not offer a doctoral program in sociology). We also talked about the best restaurants in Arlington, the academic job market, a shared love of ' $60 \mathrm{~s}$ and 70 s rock music...he was at once serious and 
personable. Ben taught a sociology of the 1960s course in the mornings, and he had to find a substitute one day. I jumped at the chance. He introduced me to his class as "an advanced graduate student, and my friend." The class and I watched performances by Jimi Hendrix, the Doors, Jefferson Airplane, and others. For Ben, sociology, writing, cultural studies-were all part of an inherently personal political project. He unabashedly stood with Marx on his eleventh thesis on Feuerbach: "heretofore the philosophers have tried to understand the world. The point, however, is to change it." I have yet to come across a work by Ben that does not make some reference to this as a foundational guiding principle in his work. Coming of age in a tumultuous era, and participating himself in youth activism, Ben spoke of the 1960s as an insider, as a member of the "New Left," and did not attempt to conceal his political perspective.

When teaching my own politically heterogeneous, principally non-majors social problems course for the first time in Fall 2016 at the University of Kansas, Agger's (2009) book The Sixties at 40 was required reading-the issues of racism, poverty and stratification, gender inequity, educational inequality, and institutional discrimination, to name just a few issues that have drawn a sociological gaze, had their roots in the $60 \mathrm{~s}$, as did our socially-constructed definitions of them as social problems. In doing so I hope to resist the subordination of the moral dimension of social problems to the technical—as Stivers (1999) puts it, 'the dominant metaphor of evil becomes 'social problem.' To use problem as a metaphor is to invoke mathematics and engineering. A problem is an obstacle, something to be solved or overcome. Social problems are not moral problems, but technical problems" (27, emphasis in original).

Yet I have many questions I never got to ask Ben. He was in some of his earlier works quite critical of what he called positivist social science-in Reading Science, which I also read that year, he critiqued its propensity for writing the author out of journal articles increasingly laden with statistical tables, charts, and graphs. "I have read journal science as a literary and hence political expression," Ben writes. "Facts are not simply facts; science writers, in reporting the world, also constitute it...Methodology solves no intellectual problems. It is rhetoric. As rhetoric, it can be engaged, opposed, even reformulated" (Agger 1989:210). Even "journal theory" or "empiricized theory" as he read it was often dense and obtuse pieces dealing with seemingly miniscule problems of interpretation from Talcott Parsons or some other theorist (179-209)_ “'Sometimes what appears to be theory, lacking data, vitiates its theoreticity shamelessly. Theory construction differs from interpretive theory in the baldness of its methodological programmatism. No punches are pulled; research is in the saddle" (203).

This is sociological theory, not social theory, and Ben's critique, as I read it, is that "journal theory" is theory, de-clawed and domesticated, rendered unable to have a transformative effect on the social world. Changing the world was not just part of the goal of sociology for Ben-it was the goal. Perhaps the difficulty of social theory, however, is a problem about which both Ben Agger and analytic philosophy have something to say, which I recently stumbled upon anew while re-reading Hillary Putnam's (1995) The Many Faces of Realism: Putnam examines the notion of "reasonableness" in the context of both ethics and science, rejecting the Weberian-Kantian move to dichotomize fact and value $(64 ; 78)$, and eschewing efforts to turn the question "why should I?" into a "means-end kind of problem," which ultimately leads Putnam to conclude:

\begin{abstract}
The fact is that we have an underived, a primitive obligation of some kind to be reasonable, not a 'moral obligation' or an 'ethical obligation,' to be sure...I also believe that it will work better in the long run for people to be reasonable, certainly; but when the question is Why do you expect that, in this unrepeatable case (Peirce's puzzle 78-83), what is extremely likely to happen will happen?, here I have to say with Wittgenstein: 'This is where my spade is turned. This is what I do, this is what I say'...This is where my justifications and explanations stop now...our moral images are in a process of development and reform (84-5).
\end{abstract}

I think Putnam's move has (dis)solved an important problem (though it does not alleviate the aforementioned modernist vertigo): replace "reasonable" with another ethically- or politically-freighted term, and one eventually, once more, reaches bedrock. Of course, once it's "turtles all the way down," even in some temporary, and possibly culturally-embedded sense, one can then begin doing empirical (but not necessarily positivist) sociology, examining who values reasonableness, why do some people rely on reasonableness more than others, and the like. Agger's move from "social facts to literary acts" resonates with this in an interesting sense, as Agger argues:

One does not need a particular version of left-wing politics-mine, for example-to agree that sociology needs to be written differently, telling a public story...stories are not equally true or good, but they cannot be resolved with reference to knowledge outside of argument itself. Although I contend that we can create a classless society, I cannot demonstrate this conclusively to people who would tell a different, perhaps Platonist or Weberian, story. My story, however well told, involves a certain circularity—my definition of social class, my theory of inequality, my conception of the good-that begs questions 
that cannot be answered without inviting further circularity (Agger 2000:256-7).

I read Agger to be suggesting that his "spade is turned" in a similar regard. Putnam knew, as many social theorists who have appended (or had appended by others) the moniker "postmodern" or "critical theory" to their work have sensed, that "the line of thinking that said, "Well if science has smashed all that [the foundations of knowledge, religion, politics, and morality], well and good. Science will give us better in its place,' now looks tired," (Putnam 1995:29); after Nietzsche, we must "philosophize without foundations" (ibid.). This does not mean there is not a world which science is aiding in understanding, but Nietzsche seemed to understand this, as did Weber: "after Nietzsche one could no longer look to science to free us from political decisions or give meaning to life" (Antonio 2015). Some of our most urgent questions as social beings raise new ontological and epistemic complexities in a post-foundational world.

In Socio(onto)logy, Agger (1989) critiqued sociology textbooks via content analysis, particularly the means by which the radical political projects of feminism and Marxism were co-opted and de-fanged as "conflict theory," "straight feminism," and the like, arguing that "The marginalia of radical dissent are disqualified; radicalism is modulated by liberal reasonableness suggesting the inevitability of some degree of hierarchy, inequality, and heterosexist family" (137, emphasis in original). Ben's critique of the practice of professional academic sociology is related to his concern for the university as a site of political activism, or perhaps more notably, lack thereof, reserving his most trenchant critiques for "many older faculty during the late 1950s and early 1960s (and even today) [who] were merely bureaucratically organized civil servants who punched in and out, refrained from rocking the boat, and published modestly on narrow topics that padded their vitae but did not change the prevailing paradigms" (Agger 2009:149) and arguing that, "The war in Vietnam gave U.S. academics few alternatives to taking sides. Faculty either helped their students avoid the draft by maintaining grade-point averages sufficiently high to retain their student deferments, or refused to do so. Faculty either marched or supported the war. They either wore a peace button or plastered an American flag on their car window. There was no middle ground" (ibid:152). I count myself fortunate to have thus far largely avoided such dilemmas - if I opposed the war, was it then my moral duty to inflate grades, or did this fatally conflict with my responsibilities as an educator? Can one love one's country — and one's institutionwhile also protesting, or rejecting, its policies? And if there is a "fatal conflict" in responsibilities as protestor and as educator, to quote the old unionist folk tune: "which side are you on"?

It was not just "the right" at which Ben took aim, but perhaps in some ways, more directly, "the center," including some of his sociologist colleagues who may have voted Democrat and agreed with Ben on many issues, yet who "are politically progressive but intellectually conservative. They respect the right of people to be gay, but hate postmodernism... Derrida has queered the western philosophical tradition by challenging foundational hierarchies, of production over reproduction, subject over object, reading over writing, straight over gay and so on" (Agger 2008:188). I do not know enough about either Derrida or queer theory to evaluate the specifics here, but this seemed part of a broader missive for sociology, and for the university. This perspective, this challenge to get "off the bench and into the game," to draw upon a sports metaphor (which Ben would have appreciated) would mean the transformation of sociology, and the university, into an expressly political site. Ben did not mince words on this: "For mainstream sociology to adopt, and thus adapt to, these three theoretical perspectives [critical theory, postmodernism, and poststructuralism] would substantially change the nature of the discipline...resist[ing] their integration into a highly differentiated, hierarchized, technical discipline that defines itself largely with reference to the original sociologies of Comte, Durkheim, and Weber, who established the positivist study of social facts and separated the vocations of science and politics" (Agger 1991:125).

This tension manifested itself in 1994, with an exchange between Fuchs and Ward, on one hand, and Agger on the other, in the prestigious disciplinary journal organ American Sociological Review. Agger (1994) takes on Fuchs and Ward's claim that in eras of Kuhnian paradigm shift, "radical" deconstruction takes over, and even basic assumptions are called into question. However, "moderate deconstruction takes over when a field organizes itself around certain assumptions that are exempt from deconstruction so that practical work can go forward" (501), arguing that "Moderate' deconstruction is not deconstruction because it embodies 'foundationalism'... Fuchs and Ward have got deconstruction wrong. Most important, they have Derrida wrong. They fail to read him as a social theorist, indeed as a left and feminist one" (501). Agger saw deconstructionism as fundamentally a radical political project which denied foundations, and lambasts the relativist and nihilist readings of deconstruction as method: "Far from being a nihilist, Derrida wants to reveal the hidden assumptions of systems in order to open public dialogue about them" (503). Fuchs and Ward (1994) reply to Agger's reply by claiming that "he has nothing at all to say about 
the substance of our argument" (506), and spending the rest of the article expounding upon disciplinary hierarchy and institutionalization: What Ben saw might have recognized as emancipatory, deliberative, iconoclastic, and valueladen sociology, Fuchs and Ward characterize as an "initial stage of youthful frivolity and playfulness" (507) that is simply a "liability of newness" (508). That is, viewing an academic field of study as born of this playfulness and excitement, "If they continue at all beyond this initial stage... They turn more and more inward, demarcating themselves from nonmembers and other specialties. After a while, celebrated intellectual and organizational leaders emerge and make authoritative pronouncements of doctrine. These leaders become the official spokespersons of the organization. They represent its agenda to an environment that would otherwise, without such spokespersons, not even register that something was going on" (507).

I get the feeling they are talking past each other. There are Weberian overtones to Fuchs and Ward's argument which bring to mind "Politics as a Vocation," (1946) stressing as it does something akin to a transition from charismatic authority in radical deconstruction to the required if not inevitable rationalization and routinization of a field's newness. The assumption that organizations arise in this way, whether it is a noted tendency or iron law, "tells a Weberian story," to note Agger's words on a classless society-namely, a Weberian story, broadly written, presumes that politics means a hierarchical distribution of power as well as intellectual and vocational specialization. Thus, radical deconstruction cannot remain radical and must become moderate- "Revolutions cannot become permanent...the previous critical opposition settles down as the new establishment” (Fuchs and Ward 1994:510). Critical theory as Ben Agger practiced it would reject this out of hand, as a means of legitimating the status quo (in this case, regarding the evolution of academic fields) by making it appear natural, rational, inevitable. There does, to deconstruct the deconstructionists, if I might, seem to be a clear political tension here, a political tension between the radical and utopian vision of a classless society and the Weberian vision of modernity as complexity, efficiency, bureaucracy, hierarchy. Fuchs and Ward are making an argument as to what is; Agger, to what ought to be, as he sees it. I see the same tension manifesting itself once again, between a piecemeal reformer like Popper who calls for working for policy change within existing institutions and the radical utopian vision of a wholly new, and truly free, world.

Indeed, Agger (2000) called for a "public sociology" in his work by that name: "sociology "is public if it embraces Marx's eleventh thesis on Feuerbach, which merges theory and practice... [and] must want to change the world, and it must recognize that it is already changing the world by intervening in it. Finally, a public sociology addresses itself to various publics, to which it doesn't condescend but seeks to mobilize" (quoted in Land 2008:507, emphasis mine). It was not sociology as a profession, as an institution, to which he paid homage, but the ideals which drove this broader intellectual project. Between 2000 and 2008, the American Sociological Association had begun taking the idea of public sociology seriously, releasing an anthology of fifteen essays devoted to the question (Clawson et. al 2007). Agger criticized these efforts by the ASA, considering in the second edition that he "should have suspected that 'public sociology' would become a brand, a convenient slogan or a label endorsed by mainstream sociologists!"” (ibid.) During this particular episode, Agger (2008) struck forcefully, opening a journal article with: "Jacques Derrida...made many mad: analytical philosophers, positivists in the science and social sciences, the right, stupid people generally" (187). He noted how "[a] colleague of mine at a former university dismissed Derridean sociology as 'speculative bullshit,' which is a lot like calling it gibberish. I thought he meant that he did not understand Derrida and thus was mad at him..." (192-3). The brunt of his critique (attack?) was the recipient of the recent ASA award for public sociology, Pepper Schwartz (2008), for her book entitled Prime: Adventures and Advice on Sex, Love, and the Sensual Years. Schwartz consulted for an on-line matchmaking site, and also for "Playboy Online"-Agger lambasts her work pubic, not public, sociology, arguing: "You have to be really self-absorbed to write a book about your sexual experiences or perhaps just needy. If Schwartz's pubic sociology cannot change the world, at least it can get you laid" (194). Later he quotes Sartre's letter to the Nobel Prize committee at length, as to why he could not accept the award, and states emphatically: "It is an iron law that you cannot be a public sociologist and rake in the cash by commodifying your work” (197).

I wish I could have talked to Ben about this article in particular. Is this irritation that his idea of public sociology has been coopted, distorted, commodified by mainstream sociology? I wonder aloud: if social science is unavoidably political, in teaching, method, research, and practice, and the body is political as well, is there not something political about Schwartz's work as well? If "the personal is political," is there not something transformative about her revealing tales? Having stood in front of a class of undergraduates and uncomfortably lectured on the sociology sex and sexuality more than once, I am convinced there is something courageous about discussing sex openly, without shame, particularly if one is not male and heterosexual, and it is a courage I largely do not possess. I have not read 
Schwartz's book, and ultimately, due to my own busy schedule or prudishness, may never. I wish I knew more about what led to this particular event. I wish Ben and I could talk about it.

\section{This is the End, the Abrupt and Unexpected End}

Ben was a Derridean feminist Marxist. I think he would like to be remembered as such. I am not a Derridean, but have gleaned insights from Ben, and others, via critical theory (sociology of knowledge, media, culture), postmodernism (religion and public reason, civil society), and poststructuralism (international relations theory, peace and conflict research), that remain an important part of my endeavors. I consider myself a feminist. But Marxism, in a Derrida's (1994) Specters of Marx sense, haunts me, as it haunts sociology, American culture, every contraction in the global economy. It would be in bad faith if I did not admit that I have serious doubts about the possibility of a classless utopia, or that I did not tend toward Weber's admittedly pessimistic formulations of industrial capitalist modernity and bureaucratic domination.

By the winter of $2014 \mathrm{I}$ had arrived at a crucial point: it was a time to decide whether, and how, to pursue a Ph.D. in sociology. Ben had helped me select schools amenable to my interests, and he encouraged me on the long and odious journey toward re-taking the Graduate Record Exam (my previous scores had expired shortly after being admitted into the UTA Master's program). I applied to nine schools, was rejected by four, wait-listed and later rejected by one, and accepted by four. I defended a proposal, and then wrote an ambitious (perhaps over-ambitious, in retrospect), Master's Thesis entitled The Idols of Modernity: The Humanity of Science and the Science of Humanity. Where Ben read, and re-read, Marcuse's (1966) Eros and Civilization I was in part inspired by Nietzsche's The Gay Science to examine the possibility of science as a fundamentally human, value-embedded, "playful" project rather than the chilly logico-mathematical edifice which perhaps no practicing scientist really believes it to be. It was a long, strange journey, and Ben, I think, was instrumental convincing the other members of my committee that I would be able to accomplish the task to which I endeavored. There was Dr. Heather Jacobson, an esteemed qualitative researcher, and the department graduate advisor, for whom I had served as a teaching assistant, and Ben's spouse, Dr. Beth Anne Shelton, an empiricist who had published influential work in gender and the family. None of this, from the day I set foot in the sociology department again in 2013, would have been possible without them.

I served as a teaching assistant for Dr. Shelton that spring, and, upon informing her of the schools to which I had been accepted, she told me: “Go to Kansas." I sat in on Ben's writing class that semester, where I met some great people and learned more about writing, including that most people, to varying degrees, even those who did it for a living, on some level hated doing it, or at least found it exhausting and frustrating. The last time I spoke to Ben was on the last class meeting of that writing seminar: he told me he had begun using "multiple guess" tests in his "Sociology of the 1960s" course, and that he was less than pleased with the result. Teaching, for Ben, was always a participatory effort — he did not really have "required" readings, saying "read around in it—sample it, get as far as you can" when pressed to clarify his reading expectations. Of course, graduate students read books without being prompted - those who like to read, it seems, are more likely to pursue this line of work in the first place!

Ben presided over the UTA center for theory, and I attended every colloquium I could, especially that spring. I heard talks on topics from Heidegger to ocean acidification, attended largely by denizens of the English department. I wonder if Ben would have felt freer, less alienated, in an English department. In any event, he contributed a great deal to sociology as theory and practice. Returning to my comment on Postponing the Postmodern, I can't help but think that Ben's vision for sociology, and the academy has indeed impacted its direction: from where I stand, scholarship seems to be more cross-disciplinary, positivism has largely fallen out of favor, and sociology has become more epistemically diverse and politically engaged. Though I pick up my ASA and regional periodicals each quarter and find a great deal of charts, tables, numbers, and figures, I also find more qualitative research, more theory, that I would have expected if the disciplinary hegemony Ben perceived, and railed against, in the late 1980s and early 1990s, was still the norm.

I had no inkling that I would be among Ben's last students. It is difficult to be referred to as such. Given his lifestyle habits — vegan runner — and mine — regular consumer of fried chicken, pizza, and craft beer-even though I am thirty years his junior, I thought he would probably outlive me. It was in the evening, mid-July. I had gone back to work at my dad's machine shop_-summers were always busy, and having a full-time job for three months helped off-set the pay cut that came with becoming a graduate teaching assistant. Dr. Jacobson called me and informed me 
of his passing after a brief illness. He was just 62 years old. I was going to see if he would be willing to meet with me, at the usual Starbucks, sometime before $8 \mathrm{am}$ the following week to chat before I left. I never got to thank him, or say good-bye.

Friends and colleagues called me that evening to invite me to an impromptu get-together, having just learned of Ben's passing, as well. I politely declined. Some crave companionship at times like that. I prefer a solitary walk in the park. I went on a really long walk that day.

We study what we study in part because of who we are as individuals. The unique life experiences we share over the course of a lifetime shape who we become, and what we study. When I hear myself saying: "You cannot stand outside the social world and view it from nowhere," I know such ideas came from Ben's work and life. Teaching my own "Social Problems and American Values" course, I assign his book The Sixties at 40 —in an age of Occupy Wall Street, Black Lives Matter, the Obergefell Supreme Court ruling in 2015, and as of November, a political apparatus once more dominated by the Right, such a work is essential for contextualizing the origin of today's most stubborn American social problems and burgeoning cultural battles. The 1960s were instrumental in Ben Agger's growth as a scholar and as a human being. My parents are his age. For me, one of the formative moments was the September 11 attacks in 2001. Today's undergraduate students were toddlers when September 11 occurred, and the 1960s probably seem like a remote period in history.

Dr. Antonio has been instrumental in helping me adjust to life in Lawrence, Kansas, in many ways exhibiting the personal kindness combined with unflinching honesty and academic rigor Ben Agger possessed. He is currently my advisor, and I am in the early stages of my dissertation proposal, researching the normative and religious dimensions of ecological stewardship. As one who is conflicted on matters of religion, I do not know what happens after death. Some believe in reincarnation, or heaven or hell, or oblivion. I hope instead to live a life that honors the memory of those who have had a profound influence along the way. Regarding Ben, that means seeing to it that I live in good faith, pursuing sociology, authoring social theory, sticking to convictions, and in general, striving to be the kind of person in whom those I have lost would take pride should they be watching.

\section{References}

Agger, Ben. 2009. The Sixties at 40: Leaders and Activists Remember and Look Forward. Boulder: Paradigm Publishers.

Agger, Ben. 2008. "Postmodern Gibberish: Derrida Dumbfounds the Positivists.” New York Journal of Sociology , 1:187-206.

Agger, Ben. 2002. Postponing the Postmodern: Sociological Practices, Selves, and Theories . Lanham: Rowman \& Littlefield Publishers, Inc.

Agger, Ben. 2000. Public Sociology: From Social Facts to Literary Acts. Lanham: Rowman \& Littlefield Publishers, Inc.

Agger, Ben. 1994. "Derrida for Sociology? A Comment on Fuchs and Ward." American Sociological Review, 59(4):501-5.

Agger, Ben. 1991. "Critical Theory, Poststructuralism, Postmodernism: Their Sociological Relevance.” Annual Review of Sociology, 17:105-31.

Agger, Ben. 1989. Reading Science: A Literary, Political, and Sociological Analysis. New York: General Hall, Inc.

Antonio, Robert J. 2015. "Nietzsche, Friedrich (1844-1900)." The Blackwell Encyclopedia of Sociology. George Ritzer, ed. Hoboken, NJ: John Wiley \& Sons, Ltd.
Clawson, Dan, Robert Zussman, Joya Misra, Naomi Gerstel, Randall Stokes, Douglas L. Anderton, and Michael Burawoy, eds. Public Sociology: Fifteen Eminent Sociolgists Debate Politics and the Profession in the Twenty-First Century. Berkeley, CA: University of California Press.

D’Amico, Robert. 1991. "Karl Popper and the Frankfurt School." TELOS 86(1):33-48.

Derrida, Jacques. 1994. Specters of Marx: The State of the Debt, the Work of Mourning, and the New International. New York: Routledge.

Eagleton, Terry. 2003. After Theory. New York: Basic Books.

Fuchs, Stephan and Steven Ward. 1994. "The Sociology and Paradoxes of Deconstruction: A Reply to Agger." American Sociological Review, 59(4):506-10.

Gerth, H.H. and C. Wright Mills. 1946. From Max Weber: Essays in Sociology. New York: Oxford University Press.

Land, Kenneth C. 2008. "Whither Public Sociology?" Contemporary Sociology, 37(6):507-11.

Mannheim, Karl. 1936. Ideology and Utopia. New York, NY: Harcourt Brace \& World, Inc. 
Marcuse, Herbert. 1966. Eros and Civilization: A Philosophical Inquiry into Freud. Boston: Beacon Press.

Marcuse, Herbert. 1964. One-Dimensional Man. Boston: Beacon Press.

Neiman, Susan. 2002. Evil in Modern Thought: An Alternative History of Philosophy. Princeton: Princeton University Press.

Nietzche, Friedrich Wilhelm and Walter A. Kaufmann. 1974. The Gay Science: With a Prelude in Rhymes and an Appendix of Songs. New York: Vintage Books.

Peele, Stanton. 1989. The Diseasing of America: Addiction Treatment Out of Control. Lexington: D.C. Heath and Company.

Putnam, Hilary. 1995. The Many Faces of Realism. Chicago: Open Court.

Ritzer, George. 2011. Sociological Theory. 8th ed. New York: McGraw-Hill.

Stivers, Richard. 1999. Technology as Magic: the Triumph of the Irrational. New York: Continuum.

Schwartz, Pepper. 2008. Prime: Adventures and Advice on Sex, Love and the Sensual Years. New York: HarperCollins.
Szrot, Lukas. 2014. "Popper, Adorno, and the Methodology Dispute" November 25. Retrieved December 3, 2016 http://www.telospress.com/author/ popper-adorno-and-the-methodology-dispute/

Valverde, Mariana. 1998. Diseases of the Will: Alcohol and the Dilemmas of Freedom. New York: Cambridge University Press.

Weber, Max. 1946. "Politics as a Vocation." From Max Weber: Essays in Sociology. H.H. Gerth and C. Wright Mills, eds. New York: Oxford University Press.

Weber, Max. 1946. "Science as a Vocation." From Max Weber: Essays in Sociology. H.H. Gerth and C. Wright Mills, eds. New York: Oxford University Press. 